\title{
Pembelajaran Sains Untuk Anak Usia Dini Dengan Model Pembelajaran Sentra Bahan Alam
}

\author{
Erna Roostin7 \& Mutiara Swandhina 8 \\ Ernaroostin72@gmail.com
}

\begin{abstract}
Science learning in early childhood education is a series of fun learning excitement to stimulate children to explore their environment and reflect on their observations and discoveries through science activities, it allows children to explore various objects, both living objects and lifelike objects around it. Children learn to find the symptoms of objects and the symptoms of events from these objects. Science also trains children using five of its sensing to identify different objects and symptom events.the child is trained to see, to feel, to smell, to feel and to hear. The more sensory involvement in learning, the child increasingly understands what is learned. The child acquires new knowledge of its sensing with various objects surrounding it, so that knowledge obtained will be useful as a further thought capital of natural materials center with science learning. The center of natural materials is filled with various media learning that comes from nature, such as water, sand, rocks, leaves. In the center of natural materials children have the opportunity to use natural media with various ways of playing according to the thoughts and ideas each with different results. The selected materials and tools must be safe and free from harmful toxic substances.this is also a unified approach in which children at the time are thinking and building a basic understanding of the world. The introduction of science for early childhood if done correctly will develop gradually the logical ability of the children have not been possessed.
\end{abstract}

Keywords: Science Learning, Natural Center

7 STKIP Sebelas April Sumedang

${ }^{8}$ STKIP Sebelas April Sumedang 


\section{PENDAHULUAN}

D. alam Undang-Undang No.20 Tahun 2003 pasal 1 ayat 14 dinyatakan bahwa "Pendidikan Anak Usia Dini (PAUD) adalah salah satu upaya pembinaan yang ditujukan pada anak sejak lahir sampai usia 6 tahun yang dilakukan melalui pemberian rangsangan pendidikan untuk membantu pertumbuhan dan perkembangan jasmani dan rohani agar anak memiliki kesiapan dalam memasuki pendidikan yang lebih lanjut". Perkembangan anak usia dini diberbagai aspek akan berkembang dengan optimal jika diberi rangsangan yang tepat. Proses pembelajaran sebagai bentuk perlakuan yang diberikan pada anak harus memperhatikan karakteristik yang dimiliki setiap tahapan perkembangan anak.

Berdasarkan hasil penelitian Carson dalam Nugraha, (2008) menyimpulkan bahwa, sains bagi anak-anak adalah segala sesuatu yang menakjubkan, sesuatu yang diketemukan dan dianggap menarik serta memberi pengetahuan atau rangsangan untuk mengetahui dan menyelidikinya. Pembelajaran sains untuk anak usia dini juga memiliki peran strategis dalam meningkatkan kualitas sumber daya manusia, antara lain melalui pembekalan keterampilan dan kebiasaan berpikir secara ilmiah, dan kemampuan analisis masalah kompleks dalam kehidupan. Pada hakikatnya sains sangat berhubungan langsung dengan anak melalui proses-proses alam yang terjadi disekeliling anak. Pengenalan tentang sains hendaknya dilakukan sejak usia dini dengan kegiatan yang menyenangkan dan melalui pembiasaan agar anak mengalami proses sains secara langsung. Maka jika pengenalan sains dilakukan dengan benar akan mengembangkan secara bertahap kemampuan berpikir logis yang belum dimiliki anak usia dini, sesuai dengan tahapan umur dan perkembangannya.

Melalui sains, anak dapat melakukan percobaan sederhana. Percobaan tersebut melatih anak menghubungkan sebab dan akibat dari suatu perlakuan sehingga melatih anak berpikir logis. Di dalam sains, anak juga berlatih menggunakan alat ukur untuk melakukan pengukuran. Alat ukur tersebut dimulai dengan alat ukur non-standar, seperti jengkal, depa, atau kaki dan dilanjutkan dengan alat ukur standar, seperti meteran dan timbangan. Anak secara bertahap berlatih menggunakan satuan yang akan memudahkan anak untuk berpikir secara logis dan rasional. Dengan demikian sains akan melatih anak untuk mengembangkan keterampilan proses sains, kemampuan berpikir logis, dan pengetahuan. Pembelajaran sains dapat dijadikan sebagai wahana untuk membangun moral, karakter dan akhlak mulia, untuk melandasi pendidikan nasional ke depan yang diwarnai dengan tekanan atau mainstream pada pembentukan watak (character building) dan perilaku. Hal ini disebabkan oleh karakteristik pembelajaran sains, yang bila diterapkan dengan benar dapat menyentuh berbagai nilai yang diperlukan dalam pembentukan karakter peserta didik, memiliki hubungan dengan berbagai konsep dalam berbagai disiplin ilmu, dan bersifat dinamis.

Model pembelajaran adalah suatu pola atau rancangan yang menggambarkan proses perincian dan penciptaan situasi lingkungna yang memungkinkan anak berinteraksi dalam pembelajaran sehingga terjadi perubahan atau perkembangan (Mulyasa, 2012). Adapun komponen model pembelajaran meliputi: konsep, tujuan pembelajaran, materi atau tema, langkah-langkah prosedur, metode, alat atau sumber belajar dan tehnik evaluasi. Ada beberapa model pembelajaran yang dilaksanakan di PAUD diantaranya adalah model pembelajaran klasikal, model pembelajaran kelompok dengan kegiatan pengaman, model pembelajaran dengan sudut-sudut kegiatan, model pembelajaran area dan model pembelajaran berdasarkan sentra. Model-model pembelajaran tersebut pada umumnya menggunakan langkah-langkah yang relative sama dalam sehari yaitu: kegiatan awal, kegiatan inti, istirahat dan kegiatan akhir atau penutup. 
Model pembalajaran di PAUD sangat menentukan berhasil tidaknya tujuan pembelajaran yang ingin di capai, model pembelajaran sentra adalah model pembelajaran yang cocok dalam pembelajaran sains untuk anak terutama sentra bahan alam, model sentra adalah pendekatan pembelajaran yang dalam proses pembelajarannya dilakukan di dalam "lingkaran" (circle times) dan sentra bermain. Lingkaran adalah saat di mana pendidik duduk bersama anak dengan posisi melingkar untuk memberikan pijakan kepada anak yang dilakukan sebelum dan sesudah bermain.

Sentra bahan alam kental dengan pengetahuan sains, matematika, dan seni. Sentra bahan alam diisi dengan berbagai bahan main yang berasal dari alam, seperti air, pasir, bebatuan, daun. Di sentra bahan alam anak memiliki kesempatan menggunakan bahan main dengan berbagai cara sesuai pikiran dan gagasan masing-masing dengan hasil yang berbeda. Pembelajaran yang berpusat pada sentra dilakukan secara tuntas mulai awal kegiatan sampai akhir dan fokus oleh satu kelompok usia PAUD dalam satu sentra kegiatan. Setiap sentra mendukung perkembangan anak dalam tiga jenis bermain yaitu bermain sensorimotor atau fungsional, bermain peran dan bermain konstruktif (membangun pemikiran anak).

\section{Pengertian Sains}

Pembelajaran sains dalam pendidikan anak usia dini merupakan serangkaian kegitan belajar yang menyenangkan untuk menstimulus anak mengeksplorasi lingkungan mereka dan merefleksikan hasil pengamatan dan penemuan mereka. Cara ini juga merupakan pendekatan terpadu di mana anakanak pada saat itu sedang berpikir dan membangun pemahaman dasar tentang dunia. Pengenalan sains untuk anak usia dini jika dilakukan dengan benar akan mengembangkan secara bertahap kemampuan berpikir logis yang belum dimiliki anak.

Ada beberapa ahli yang mengemukakan sejumlah pengertian dan batasan sains diantaranya Conant dalam tulisan Oktriyani (2012) berpendapat bahwa Sains sebagai suatu deretan konsep serta skema konseptual yang berhubungan satu sama lain, yang tumbuh sebagai hasil serangkaian percobaan dan pengamatan serta dapat diamati dan diuji cobakan lebih lanjut (Nugraha, 2008).

Sedangkan Kilmer dan Hofman (1995) berpendapat bahwa "sains merupakan pengetahuan tentang fenomena-fenomena tertentu, proses yang digunakan untuk mengumpulkan dan mengevaluasi informasi, dan sebagai bentuk adaptasi manusia pada lingkungan". Sains bukan hanya kumpulan fakta dan hafalan rumus saat belajar melainkan jua mencakup prinsip-prinsip, prosedur, dan sikap ilmiah. Pendapat diatas sejalan dengan pemikiran Nugraha yang menyatakan bahwa "Sains merupakan suatu kesatuan dari proses, produk dan sikap" (Nugraha, 2008).

Melalui kegiatan sains memungkinkan anak melakukan eksplorasi terhadap berbagai benda, baik benda hidup maupun benda tak hidup yang ada disekitarnya. Anak belajar menemukan gejala benda dan gejala peristiwa dari benda-benda tersebut. Sains juga melatih anak menggunakan lima inderanya untuk mengenal berbagai gejala benda dan gejala peristiwa. Anak dilatih untuk melihat, meraba, membau, merasakan dan mendengar. Semakin banyak keterlibatan indera dalam belajar, anak semakin memahami apa yang dipelajari. Anak memperoleh pengetahuan baru hasil penginderaanya dengan berbagai benda yang ada disekitarnya, sehingga pengetahuan yang diperolehnya akan berguna sebagai modal berpikir lanjut.

Selain itu melalui proses sains, anak dapat melakukan percobaan sederhana yang mana percobaan tersebut melatih anak menghubungkan sebab dan akibat dari suatu perlakuan sehingga 
melatih anak berpikir logis. Dalam pembelajaran sains, anak juga berlatih menggunakan alat ukur untuk melakukan pengukuran. Alat ukur tersebut dimulai dari alat ukur nonstandar, seperti jengkal, depa atau kaki. Anak secara bertahap berlatih menggunakan satuan yang akan memudahkan mereka untuk berfikir secara logis dan rasional. Dengan demikian sains juga mengembangkan kemampuan intelektual anak.

\section{Pentingnya Pembelajaran Sains Bagi Anak Usia Dini}

Seperti yang telah dijelaskan sebelumnya, bahwa pembelajaran sains pada anak usia dini bermanfaat untuk meningkatkan perkembangan anak terutama kognitif, salah satunya anak dalam memahami konsep-konsep sains dan keterkaitannya dengan kehidupan sehari-hari, memiliki keterampilan proses dan aktivitas belajar untuk mengembangkan pengetahuan tentang alam sekitar, serta mampu menggunakan metode ilmiah dan bersikap ilmiah untuk memecahkan masalah-masalah yang dihadapinya dengan lebih menyadari kebesaran dan kekuasaan pencipta alam semesta. Mubarok (2008) mengemukakan bahwa "pengajaran sains adalah pengajaran yang tidak menuntut hafalan, tetapi pengajaran yang banyak memberikan latihan untuk mengembangkan cara berfikir yang sehat dan masuk akal berdasarkan kaidah-kaidah sains".

Pengenalan sains bagi anak usia dini memiliki peranan yang penting dalam peningkatan mutu pendidikan, khususnya dalam menghasilkan anak yang mampu berpikir kritis, logis, dan kreatif yang harus dilatih sejak usia dini supaya dapat berkembang menjadi mental yang positif bagi anak di masa yang akan datang. Pengembangan kemampuan sains pada anak usia dini, memiliki peranan yang sangat penting dalam membantu meletakkan dasar kemampuan dan pembentukkan sumber daya menusia yang diharapkan (Latif, et al. 2016).

Kesadaran akan pentingnya pembekalan sains pada anak semakin tinggi apabila menyadari bahwa kita hidup dalam dunia yang dinamis, berkembang dan berubah secara terus-menerus bahkan makin menuju masa depan, semakin memerlukan sains seiring dengan berkembangnya teknologi sains diera gloalisasi sekarang ini. Seperti yang diutarakan Nugraha bahwa "Anak yang telah dibekali dengan kemampuan sains dengan anak yang belum atau tidak dibekali kemampuan sains akan terlihat berbeda, perbedaan itu bisa kita lihat antara lain ketika anak kurang dapat memecahkan masalah, mudah menyimpulkan sesuatu tanpa dilihat kebenarannya, dan anak kurang memiliki kemampuan berpikir kritis atau lebih cenderung pasif serta kurang memiliki inisiatif terhadap suatu persoalan yang dihadapi.

\section{Tujuan Pembelajaran Sains di PAUD}

Pembelajaran sains pada anak usia dini sangat penting untuk memberikan bekal ilmu pengetahuan kepada anak tentang alam dan segala isinya yang memberikan makna terhadap kehidupannya di masa yang akan datang. Leeper (1994) mengemukakan tujuan pembelajaran sains bagi anak usia dini adalah sebagai berikut:

a. Agar anak-anak memiliki kemampuan memecahkan masalah yang dihadapinya melalui penggunaan metode sains, sehingga anak-anak terbantu dan menjadi terampil dalam menyelesaikan berbagai hal yang dihadapinya.

b. Agar anak memiliki sikap ilmiah. Hal-hal yang mendasar, misalnya: tidak cepat-cepat dalam mengambil keputusan, dapat melihat sesuatu dari berbagai sudut pandang, berhati-hati terhadap informasi yang diterimanya serta bersifat terbuka. 
c. Agar anak-anak mendapatkan penngetahuan dan informasi ilmiah yang lebih baik dan dapat dipercaya, artinya informasi yang diperoleh anak berdasarkan pada standar keilmuan yang semestinya, karena informasi yang disajikan merupakan hasil temuan dan rumusan yang obyektif serta sesuai dengan kaidah-kaidah keilmuan yang menaunginya.

d. Agar anak lebih berminat dan tertarik untuk menghayati sains yang berada dan ditemukan di lingkungan dan alam sekitarnya.

Berdasarkan tujuan tersebut, jelaslah bahwa pengembangan pembelajaran sains bukan saja membina domain kognitif anak saja, melainkan membina aspek afektif dan psikomotor secara seimbang, bahkan lebih jauh diharapkan dengan mengembangkan pembelajaran sains yang memadai (adequate) akan menumbuhkan kreativitas dan kemampuan berfikir kritis yang semuanya akan sangat bermanfaat bagi aktualisasi dan kesiapan anak untuk menghadapi perannya yang lebih luas dan kompleks pada masa akan datang.

\section{Pembelajaran Sains di PAUD}

a. Perencanaan Pembelajaran Sains di PAUD

Pembelajaran pada dasarnya merupakan proses aktifitas yang dilakukan secara tertata dan teratur, berjalan secara logis dan sistematis mengikuti aturan-aturan yang disepakati dan yang tercantum dalam kurikulum, agar dalam pelaksanaannya dapat mencapai hasil yang diharapkan. Pengaturan tersebut dituangkan dalam bentuk perencanaan pembelajaran. Setiap perencanaan selalu berkenaan dengan perkiraan atau proyeksi mengenai apa yang diperlukan dan apa yang akan dilakukan. Perencanaan adalah suatu cara yang memuaskan untuk membuat kegiatan dapat berjalan dengan baik, disertai dengan berbagai langkah yang antisipatif guna memperkecil kesenjangan yang terjadi sehingga kegiatan tersebut mencapai tujuan yang telah ditetapkan, demikian diungkapkan oleh Uno (2008). Menurut Sujana dalam tulisan Nugraha, (2008:109). batasan perencanaan pembelajaran akan tepat sesuai dengan jumlah aspek-aspek, apabila aspek yang terkait dengan pembelajaran sains meliputi tujuan, dukungan material yang dibutuhkan, menyiapkan anak, mengembangkan kegiatan, penguatan dan penghargaan, lembar kerja anak dan evaluasi. Maka batasan dari perencanaan pembelajaran adalah memproyeksikan atau memprediksi serta memperkirakan hal-hal yang diperlukan sebagaimana kebutuhan dari unsur-unsur yang teridentifikasi.

\section{b. Metode Pembelajaran Sains di PAUD}

Metode merupakan cara yang dalam fungsinya merupakan alat untuk mencapai tujuan kegiatan. Sebagai alat untuk mencapai tujuan tidak selamanya berfungsi secara memadai. Oleh karena itu, dalam memilih suatu metode yang akan di pergunakan dalam program kegiatan anak di taman kanak-kanak guru perlu mempunyai alasan yang kuat dan faktor-faktor yang mendukung pemilihan metode tersebut, seperti: karakteristik tujuan kegiatan dan karakteristik anak yang diajar. Metode yang di gunakan untuk mengembangkan kognisi anak yaitu metode yang mampu menggerakkan anak agar dapat berfikir, menalar, mampu menarik kesimpulan, dan membuat generalisasi. Caranya adalah dengan memahami lingkungan di sekitarnya, mengenal orang dan benda-benda yang ada, memahami tubuh dan perasaan mereka sendiri, melatih memahami untuk mengurus diri sendiri. Selain itu melatih anak menggunakan bahasa untuk berhubungan dengan orang lain, dan melakukan apa yang dianggap benar berdasarkan nilai yang ada dalam masyarakat. Metode yang di pilih untuk meningkatkan sains anak adalah metode yang dapat menggerakkan anak untuk meningkatkan motivasi, rasa ingin tahu, dan mengembangkan imajinasi. Dalam mengembangkan sains anak metode yang dipergunakan mampu mendorong anak mencari dan menemukan jawabannya, membuat pertanyaan yang membantu memecahkan, memikirkan kembali, membangun kembali, dan menemukan hubungan-hubungan baru. Metode 
pembelajaran yang sesuai dengan karakteristik anak usia dini yaitu bermain, karyawisata, bercakapcakap, bercerita, demonstrasi, proyek dan pemberian tugas. Melalui metode pembelajaran tersebut guru dapat memfariasikan metode tersebut sehingga menarik minat anak dalam pembelajaran sains dan anak tidak salah konsep dalam pembelajaran sains, metode pembelajaran di PAUD, seperti: tanya jawab, demostrasi, bermain, proyek, pemberian tugas, bercerita, eksperimen, dan karya wisata.

\section{c. Model Pembelajaran Sains di PAUD}

Model pembelajaran adalah pola yang digunakan guru dalam melaksanakan kegiatan pembelajaran dalam rangka membantu anak mencapai hasil belajar tertentu (Depdiknas, 2005). Menurut Sujiono (2009) model pembelajaran pada anak usia dini terdiri dari dua jenis, yaitu pembelajaran yang berpusat pada guru dan pembelajaran yang berpusat pada anak. Model pembelajaran yang berpusat pada anak terdiri dari model pembelajaran kelompok dan model pembelajaran berdasarkan minat. Penyusunan model pembelajaran didasarkan pada silabus yang dikembangkan menjadi Program Semester (Prosem), Rencana Program Pembelajaran Mingguan (RPPM), dan Rencana Program Pembelajaran Harian (RPPH). Dengan demikian model pembelajaran merupakan gambaran konkrit yang dilakukan pendidik dan peserta didik sesuai dengan Rencana Kegiatan Harian. Ada beberapa model pembelajaran yang dilaksanakan di pendidikan anak usia dini, diantaranya adalah Model Pembelajaran Klasikal, Model Pembelajaran Kelompok dengan kegiatan pengaman, Model pembelajaran berdasarkan sudut-sudut kegiatan, model pembelajaran area, dan model pembelajaran berdasarkan sentra. Model-model pembelajaran tersebut pada umumnya menggunakan langkah-langkah yang relative sama dalam sehari, yaitu: kegiatan awal, kegiatan inti, istirahat, dan kegiatan akhir atau penutup.

\section{d. Media pembelajaran Sains di PAUD}

Media pembelajaran secara umum adalah alat bantu proses belajar-mengajar. Rossi dan Breidle (dalam Sanjaya 2012) mengemukakan bahwa media pembelajaran adalah seluruh alat dan bahan yang dapat dipakai untuk mencapai tujuan pendidikan, seperti radio, televisi, buku, koran, majalah dan sebagainya. Menurut Gagne (dalam Sumarno, 2011), media pembelajaran adalah jenis komponen dalam lingkungan siswa yang dapat merangsang mereka untuk belajar. Adapun beberapa tujuan menggunakan media pembelajaran diantaranya adalah mempermudah proses belajar-mengajar, meningkatkan efisien belajar-mengajar, menjaga relevansi dengan tujuan pembelajaran. membantu konsentrasi anak, komponen sumber belajar yang dapat merangsang anak untuk belajar, wahana fisik yang mengandung materi instruksional

\section{Model Pembelajaran Sentra Bahan Alam}

Model pembalajaran sentra adalah pendekatan pembelajaran yang dalam proses pembelajarannya dilakukan di dalam "lingkaran" (circle times) dan sentra bermain. Lingkaran adalah saat di mana guru duduk bersama anak dengan posisi melingkar untuk memberikan pijakan kepada anak yang dilakukan sebelum dan sesudah bermain (Retno \& Wismiarti, 2010). Sentra bermain adalah zona atau arena bermain anak yang dilengkap dengan seperangkat alat bermain yang berfungsi sebagai pijakan lingkaran yang diperlukan untuk mengembangkan seluruh potensi dasar anak didik dalam berbagai aspek perkembangan secara seimbang. Sentra yang dibuka setiap harinya disesuaikan dengan jumlah kelompok di setiap PAUD. Pembelajaran yang berpusat pada sentra dilakukan secara tuntas mulai awal kegiatan sampai akhir dan fokus oleh satu kelompok usia PAUD dalam satu sentra kegiatan. Setiap sentra mendukung perkembangan anak dalam tiga jenis bermain yaitu bermain sensorimotor atau fungsional, bermain peran dan bermain konstruktif (membangun pemikiran anak). Ada bermacam-macam sentra yang ada di PAUD seperti: sentra persiapan, imtaq, balok, main peran, 
seni, memasak, dan bahan alam. Sentra bahan alam kental dengan pembelajaran sains, matematika, dan seni. Sentra bahan alam diisi dengan berbagai bahan main yang berasal dari alam, seperti air, pasir, bebatuan, daun. Di sentra bahan alam anak memiliki kesempatan menggunakan bahan main dengan berbagai cara sesuai pikiran dan gagasan masing-masing dengan hasil yang berbeda. Gunakan bahan dan alat yang ada disekitar. Bahan dan alat yang digunakan harus bebas dari bahan beracun atau binatang kecil yang membahayakan.

Sains melatih anak menggunakan lima inderanya untuk mengenal berbagai gejala benda dan gejala peristiwa. Anak dilatih untuk melihat, meraba, membau, merasakan dan mendengar. Semakin banyak keterlibatan indera dalam belajar, anak semakin memahami apa yang dipelajari. Anak memperoleh pengetahuan baru hasil penginderaanya dengan berbagai benda yang ada disekitarnya, sehingga pengetahuan yang diperolehnya akan berguna sebagai modal berpikir lanjut. Kesadaran akan pentingnya pembekalan sains pada anak semakin tinggi apabila menyadari bahwa kita hidup dalam dunia yang dinamis, berkembang dan berubah secara terus-menerus, semakin memerlukan sains seiring dengan berkembangnya teknologi sains diera gloalisasi sekarang ini.

Pembelajaran harus berjalan secara logis dan sistematis mengikuti aturan-aturan yang disepakati dan yang tercantum dalam kurikulum, agar dalam pelaksanaannya dapat mencapai hasil yang diharapkan, maka perlu dibuat perencanaan. Dalam perencanaan guru menentukan metode pembelaran dan model pembelajaran yang sesuai dengan tema kegiatan, disamping itu guru harus memilih dan menentukan media yang tepat. Salah satu model pembelajaran yang sesuai dengan pembelajaran sains adalah model pembelajaran sentra bahan alam, karena sentra bahan alam kental dengan pembelajaran sains. Sentra bahan alam diisi dengan berbagai bahan main yang berasal dari alam, seperti air, pasir, bebatuan, daun. Di sentra bahan alam anak memiliki kesempatan menggunakan bahan main dengan berbagai cara sesuai pikiran dan gagasan masing-masing dengan hasil yang berbeda.

\section{METODE PENELITIAN}

Pendekatan dalam penelitian ini menggunakan studi literatur yaitu kegiatan yang berkenaan dengan metode pengumpulan data pustaka, membaca, mencatat dan menganalisa, tujuannya adalah untuk memperkuat permasalahan serta sebagai dasar teori dalam melakukan studi. Dalam hal ini mengelaborasikan secara sistematis tentang pembelajaran sains untuk anak usia dini dengan model pembelajaran sentra bahan alam.

\section{PEMBAHASAN}

Pembelajaran sains pada anak usia dini sangat penting untuk memberikan bekal ilmu pengetahuan kepada anak tentang alam dan segala isinya. Pembelajaran sains tidak hanya membina domain kognitif anak, melainkan membina aspek afektif dan psikomotor secara seimbang. Lebih jauh diharapkan dengan mengembangkan pembelajaran sains yang memadai akan menumbuhkan kreativitas dan kemampuan berpikir kritis yang semuanya akan sangat bermanfaat bagi aktualisasi dan kesiapan anak menjadi generasi berkualitas untuk menghadapi perannya yang lebih luas dan kompleks pada masa akan datang. Sejak lahir anak memiliki lebih kurang 100 miliar sel otak, sel-sel saraf ini harus rutin distimulasi dan didayagunakan agar terus berkembang jumlahnya. Pertumbuhan otak anak sangat dipengaruhi oleh bagaimana cara orangtua mengasuh dan asupan gizi serta stimulasi pendidikan. Dari aspek pendidikan, stimulasi sejak dini sangat diperlukan guna memberikan 
rangsangan terhadap seluruh aspek perkembangan anak yang mencakup penanaman nilai-nilai dasar, pembentukan sikap (disiplin dan kemandirian), dan pengembangan kemampuan dasar (berbahasa, motorik, kognitif, dan sosial). Pemberian stimulasi pendidikan adalah hal sangat penting, sebab $80 \%$ pertumbuhan otak berkembang pada anak sejak usia dini. Kemudian, elastisitas perkembangan otak anak usia dini lebih besar pada usia lahir hingga sebelum 8 tahun kehidupannya, 20\% sisanya ditentukan selama sisa kehidupannya setelah masa kanak-kanak. Bentuk stimulasi yang diberikan harusnya dengan cara yang tepat sesuai dengan tingkat perkembangannya. Besarnya rasa ingin tahu anak yang merupakan bawaan sejak lahir terhadap sesuatu yang ada disekitarnya, tampak pada saat anak melakukan kegiatan sains. Mengenalkan sains pada anak usia dini harus sesuai dengan tahapan umur dan perkembangannya. Suasana harus dijaga supaya tetap menyenangkan, sehingga anak dalam kondisi ceria akan bertanya mengapa bisa begitu? terus nanti bagaimana? dan sebagainya. Dalam situasi bermain itulah kita dapat melakukan eksperimen sainsSains melatih anak bereksperimen dengan melaksanakan beberapa percobaan, memperkaya wawasan anak untuk selalu ingin mencoba dan mencoba. Sehingga sains dapat mengarahkan dan mendorong anak menjadi seorang yang kreatif dan penuh inisiatif. Sains membiasakan anak-anak mengikuti tahap-tahap eksperimen dan tak boleh menyembunyikan suatu kegagalan. Artinya, sains dapat melatih mental positif, berpikir logis, dan sistematis.

Di samping itu, dapat pula melatih anak bersikap cermat, karena anak harus mengamati, menyusun prediksi, dan mengambil keputusan. Pengalaman belajar yang diperoleh anak dari lingkungan, melalui cara mengamati, meniru dan bereksperimen yang berlangsung secara berulangulang, termasuk stimulasi yang akan mempengaruhi seluruh potensi dan kecerdasan anak. Oleh karena itu, diperlukan upaya yang mampu memfasilitasi anak dalam masa tumbuh kembangnya berupa kegiatan pendidikan dan pembelajaran sesuai dengan usia, kebutuhan dan minat anak. Model pembalajaran di PAUD sangat menentukan berhasil tidaknya tujuan pembelajaran yang ingin di capai, model pembelajaran sentra adalah model pembelajaran yang cocok dalam pembelajaran sains untuk anak terutama sentra bahan alam, model sentra adalah pendekatan pembelajaran yang dalam proses pembelajarannya dilakukan di dalam "lingkaran" (circle times) dan sentra bermain. Lingkaran adalah saat di mana pendidik duduk bersama anak dengan posisi melingkar untuk memberikan pijakan kepada anak yang dilakukan sebelum dan sesudah bermain. Sentra bahan alam kental dengan pengetahuan sains, matematika, dan seni. Sentra bahan alam diisi dengan berbagai bahan main yang berasal dari alam, seperti air, pasir, bebatuan, daun. Di sentra bahan alam anak memiliki kesempatan menggunakan bahan main dengan berbagai cara sesuai pikiran dan gagasan masing-masing dengan hasil yang berbeda. Pembelajaran yang berpusat pada sentra dilakukan secara tuntas mulai awal kegiatan sampai akhir dan fokus oleh satu kelompok usia PAUD dalam satu sentra kegiatan. Setiap sentra mendukung perkembangan anak dalam tiga jenis bermain yaitu bermain sensorimotor atau fungsional, bermain peran dan bermain konstruktif (membangun pemikiran anak).

\section{KESIMPULAN}

Sains melatih anak menggunakan lima inderanya untuk mengenal berbagai gejala benda dan gejala peristiwa. Anak dilatih untuk melihat, meraba, membau, merasakan dan mendengar. Semakin banyak keterlibatan indera dalam belajar, anak semakin memahami apa yang dipelajari. Anak memperoleh pengetahuan baru hasil penginderaanya dengan berbagai benda yang ada disekitarnya, sehingga pengetahuan yang diperolehnya akan berguna sebagai modal berpikir lanjut. Kesadaran akan pentingnya pembekalan sains pada anak semakin tinggi apabila menyadari bahwa kita hidup dalam 
dunia yang dinamis, berkembang dan berubah secara terus-menerus, semakin memerlukan sains seiring dengan berkembangnya teknologi sains diera gloalisasi sekarang ini.

Pembelajaran harus berjalan secara logis dan sistematis mengikuti aturan-aturan yang disepakati dan yang tercantum dalam kurikulum, agar dalam pelaksanaannya dapat mencapai hasil yang diharapkan, maka perlu dibuat perencanaan. Dalam perencanaan guru menentukan metode pembelaran dan model pembelajaran yang sesuai dengan tema kegiatan, disamping itu guru harus memilih dan menentukan media yang tepat. Salah satu model pembelajaran yang sesuai dengan pembelajaran sains adalah model pembelajaran sentra bahan alam, karena sentra bahan alam kental dengan pembelajaran sains. Sentra bahan alam diisi dengan berbagai bahan main yang berasal dari alam, seperti air, pasir, bebatuan, daun. Di sentra bahan alam anak memiliki kesempatan menggunakan bahan main dengan berbagai cara sesuai pikiran dan gagasan masing-masing dengan hasil yang berbeda.

\section{DAFTAR PUSTAKA}

Hofman, H., \& Kilmer, S. J. (1995). Transforming science curriculum. In S. Bredekamp \& Rosegrant, T. (Eds.). Reaching Potentials: Transforming Early Childhood Curriculum and Assessment Volume 2. Washigton DC, NAEYC: 259-279

Latif, M., Zukhairina, Zubaidah, R., \& Afandi, M. (2016). Orientasi Baru Pendidikan Anak Usia Dini: Teori Dan Aplikasi. Jakarta: PT Fajar Interpratama Mandiri.

Nugraha, A. (2008). Pengembangan Pembelajaran Sains Pada Anak Usia Dini. Bandung: JILSI Foundation.

Oktriyani, N. (2012). Pengembangan Pembelajaran Sains Pada Anak Usia Dini.http://novaoktriyani. blogspot.com diakses pada tanggal 17 February 2015.

Retno, S., \& Wismiarti (2010) Sentra Persiapan. Jakarta Timur: Penerbit Pustaka Al- Falah

Sanjaya, W. (2012). Perencanaan dan Desain Sistem Pembelajaran. Jakarta: Kencana.

Sujion, Yuliani. (2011). Konsep Dasar Pendidikan Anak Usia Dini. Jakarta: Indeks.

Sumarno, A. (2011). Pengertian Hasil Belajar, (http://elearning. unesa.ac.id/tag/teori-hasil-belajargagne-dan-driscoll-dalam-buku-apa)

Uno, H. B. (2008). Perencanaan Pembelajaran. Jakarta: PT Bumi Aksara. 